\title{
The pattern of Food Additives Consumption among Preschool Children and Knowledge and Attitude of their mothers in Al Sharkia Governorate, Egypt
}

\author{
${ }^{1}$ Mona S. Hamed, ${ }^{2}$ Noha O. Ferer, ${ }^{1}$ Hanaa A. Nofal, \\ ${ }^{1}$ Department of community, environmental and occupational medicine, ${ }^{2}$ Department of \\ Family Medicine, Faculty of Medicine, Zagazig University, Egypt.
}

Submission Date: 2020-09-21Ｒevision Date: 2020-11-17 Acceptance Date: 2020-11-18

\begin{abstract}
Background: Many nutritionists suggest that preschool children have the highest exposure to food additives which are an essential element in the spread of snaking culture and are often responsible for the increased prevalence of non-communicable diseases. Objectives: To assess the magnitude and the pattern of food additives consumption among preschool children and to assess knowledge and attitude towards E-numbers and food additives among mothers. Methods: A cross-sectional study was conducted on 514 preschool children. a structured questionnaire was designed to assess food additives consumption, knowledge, and attitude of mothers toward food additive, also food labels of 60 marketed products were analysed. Results: This survey revealed that daily food additives consumption was found among $15 \%$ of the studied children, $30 \%$ of food products contain two or three additives belonging to dairy, meat products, and crisps, the citric acid (E330) was found in all selected food categories except in dairy and meat products. $72 \%$ of the participants' mothers had poor knowledge of food additives, knowledge level was increased with higher Socioeconomic status. There was a significant negative correlation between Socioeconomic status, total knowledge of mothers, and food additives consumption. Conclusion: Daily food additives consumption is related to poor knowledge and negative attitudes of mothers which should be defeated by consumer educational programs on food additives.
\end{abstract}

Keywords: Awareness, E-numbers, Children, Food labels, nutritional habits.

Corresponding author: Mona Sami Hamed Mohamed Email : drmonasami@yahoo.com

\section{Introduction}

A food additive is defined as any substance added to food for the technological purpose either in the preparation, processing, manufacture, packaging, treatment, transport, even storage. As a rule, food added substances are not consumed as food by themselves and not regularly utilized as a typical element of the food, regardless of whether they have nutritive value. The term does exclude "contaminants" or substances added to food for maintaining or improving dietary characteristics. ${ }^{1}$

More than 10000 chemicals are allowed in the United States as food additives under the 1958 Food Additives Amendment to the 1938 Federal Food Drug and Cosmetic Act (Public Law 85-929). About 1000 synthetic substances are utilized under a "Generally Recognized as Safe" (GRAS) designation without the US Food and Drug 
Administration (FDA) approval or notification. $^{2}$

The acceptable daily intake of food additives (ADI) is the amount of a food additive (expressed on a bodyweight basis), which can be ingested daily during an entire lifetime without appreciable health risk. ${ }^{3}$

The study conducted in Brazil by Lorenzoni et al. ${ }^{4}$ showed that 506 products were classified as children products, from which $92 \%$ of these products contained information on their ingredients (and additives) and $86.5 \%$ of these studied products contained at least one additive in their formulation. The most used additives were lecithin $(45.30 \%)$ and citric acid $(22.86 \%)$ and artificial dyes Allura red (9.83\%), tartrazine $(6.84 \%)$, and $5.77 \%$ for both sunset yellow or brilliant blue.

Evidence from nonhuman laboratory and human epidemiologic studies recommends that direct and indirect food added substances may cause morbidities and disability in the population, direct food additives like "colorings, flavorings, chemicals added to food during processing" while indirect food additives are substances which not added intentionally to food as food contact materials including adhesives, dyes, coatings, paper, paperboard, plastic, and other polymers. ${ }^{5}$

Food additives may attribute to the spread of snaking culture as well as the commercial success of junk foods, it was claimed to be responsible for the increased occurrence of non-communicable diseases. ${ }^{6}$ Many studies indicate several adverse effects to food additives, either in acute or chronic forms, such as toxic reactions in metabolism, triggering allergies, ${ }^{7}$ carcinogenicity in animals, ${ }^{8}$ probable carcinogenicity in humans, ${ }^{9}$ and behavioral changes. ${ }^{10-11}$
Hazards of food additives linked obviously to children's health because children may be highly exposed compared with adults either due to greater dietary intake per pound, their underdeveloped detoxification systems, and immature organs. ${ }^{12}$ It was recommended by JECFA that no additives be used in foods for children under one year and despite that, there are several products, such as yogurt, jellies, soft drinks, cookies, and candy, are consumed by both children and adults. ${ }^{13}$

Childhood, particularly the preschool age, is a time of rapid growth and development. It is a period when many key organ and tissue systems in the body grow and mature. ${ }^{14}$ Thus, the potential exists for these developmental processes to be disrupted by exposure to chemicals in high doses. ${ }^{15-16}$

As the preschool age is particularly vulnerable due to changing dietary habits with the introduction of complementary foods in place of a milk-based food, Furthermore, the limited range of foods items consumed during preschool age may lead to increased additives intake present in specific and highly consumed foods, All these factors denote that preschool children are likely to have the highest exposure to food additives

Because of lacking local records in Egypt on the levels of children's food additive consumption, dietary estimates and the associated health hazards are not clear. Thus, a study of food additives consumption in preschool children is urgently needed to investigate the situation locally.

The study aimed to assess the magnitude and the pattern of food additives consumption among preschool children and to assess knowledge and attitude towards E-numbers and food additives among mothers, for decreasing bad 
nutritional habits and morbidities resulting from food additives consumption.

Research question: What are the magnitude and the pattern of food additives consumption among preschool children, and what are their mothers' knowledge and attitude towards Enumbers and food additives?

\section{Method}

Study design and sampling method: A cross-sectional study was conducted on 514

Table (1): Basic Sociodemographic characteristics and anthropometric assessment of the studied preschool children $(\mathrm{n}=514)$

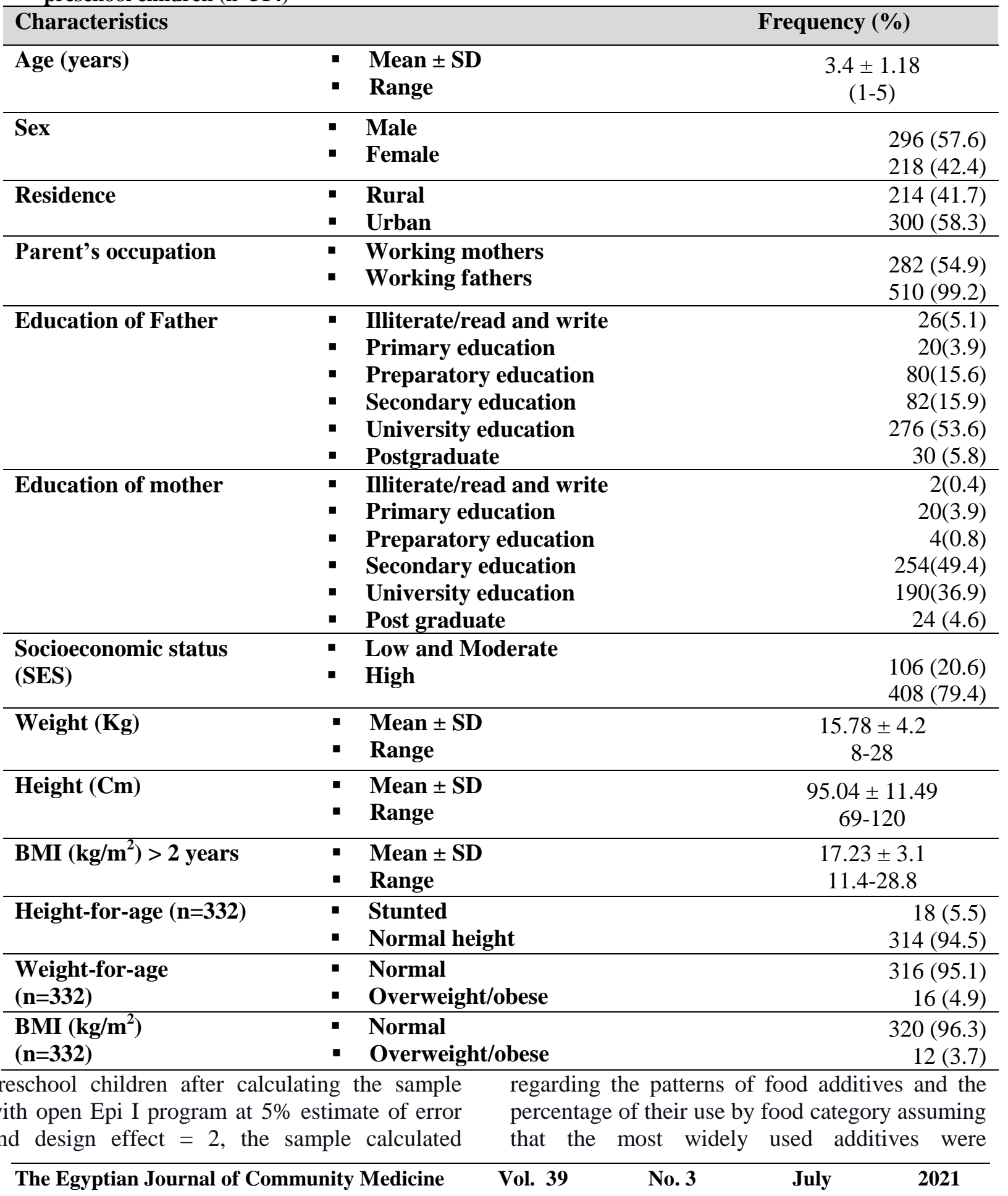


flavorings, which are present in $78.85 \%$ of the products consumed by preschool children ${ }^{4}$ and the number of preschool children in Sharika governorate was 867129 child according to Egypt DHS 2017. ${ }^{17}$ Through a multistage sampling technique, Zagazig and Belbeis districts were selected by simple random technique to represent Sharkia governorate (which consisted of 13 districts, and about

Table (2): Food additives consumption among the studied children

\begin{tabular}{|c|c|c|c|c|c|c|c|}
\hline \multirow[b]{2}{*}{$\underset{\ddagger \text { ready made }}{\text { food item }}$} & \multicolumn{7}{|c|}{ Consumption frequency among the studied children $(n=514)$} \\
\hline & $\begin{array}{c}\text { more than } \\
\text { once/day }\end{array}$ & $\begin{array}{l}\text { once } \\
\text { /day }\end{array}$ & $\begin{array}{c}\text { 4-5 } \\
\text { /weekly }\end{array}$ & $\begin{array}{c}\text { 2-3 } \\
\text { weekly }\end{array}$ & $\begin{array}{c}\text { once } \\
\text { weekly }\end{array}$ & $\begin{array}{c}\text { once or } \\
\quad< \\
\text { monthly }\end{array}$ & No \\
\hline $\begin{array}{l}\text { Crisps \& crackers } \\
\text { (Chips, wheat crackers \& } \\
\text { corn crackers) }\end{array}$ & $\begin{array}{c}30 \\
(5.8 \%) \\
\end{array}$ & $\begin{array}{c}49 \\
(9.5 \%) \\
\end{array}$ & $\begin{array}{c}85 \\
(16.5 \%) \\
\end{array}$ & $\begin{array}{c}88 \\
(17.1 \%) \\
\end{array}$ & $\begin{array}{c}126 \\
(24.5 \%) \\
\end{array}$ & $\begin{array}{c}115 \\
(22.5 \%) \\
\end{array}$ & $\begin{array}{c}21 \\
(4.1 \%) \\
\end{array}$ \\
\hline $\begin{array}{l}\text { Cereals, Biscuits \& Cakes } \\
\text { (Bakery, pies, }{ }^{*} \text { pizza, Noodles } \\
\text { \& pasta, Biscuits, Cakes and } \\
\text { Fries) }\end{array}$ & $\begin{array}{c}36 \\
(7.0 \%) \\
\end{array}$ & $\begin{array}{c}71 \\
(13.8 \%) \\
\end{array}$ & $\begin{array}{c}68 \\
(13.2 \%) \\
\end{array}$ & $\begin{array}{c}66 \\
(12.8 \%) \\
\end{array}$ & $\begin{array}{c}84 \\
(16.3 \%) \\
\end{array}$ & $\begin{array}{c}132 \\
(25.7 \%) \\
\end{array}$ & $\begin{array}{c}57 \\
(11.2 \%) \\
\end{array}$ \\
\hline $\begin{array}{l}\text { Juices \& Beverages } \\
\text { (Juices and Soda beverages) }\end{array}$ & $\begin{array}{c}13 \\
(2.5 \%) \\
\end{array}$ & $\begin{array}{c}49 \\
(9.5 \%) \\
\end{array}$ & $\begin{array}{c}35 \\
(6.8 \%) \\
\end{array}$ & $\begin{array}{c}75 \\
(14.6 \%) \\
\end{array}$ & $\begin{array}{c}79 \\
(15.4 \%) \\
\end{array}$ & $\begin{array}{c}179 \\
(34.8 \%) \\
\end{array}$ & $\begin{array}{c}84 \\
(16.4 \%) \\
\end{array}$ \\
\hline $\begin{array}{l}\text { Candies \& chocolate } \\
\text { (Candies, lollipops and } \\
\text { Chocolate) }\end{array}$ & $\begin{array}{c}33 \\
(6.4 \%) \\
\end{array}$ & $\begin{array}{c}119 \\
(23.2 \%)\end{array}$ & $\begin{array}{c}105 \\
(20.4 \%)\end{array}$ & $\begin{array}{c}84 \\
(16.3 \%) \\
\end{array}$ & $\begin{array}{c}88 \\
(17.2 \%) \\
\end{array}$ & $\begin{array}{c}50 \\
(9.7 \%) \\
\end{array}$ & $\begin{array}{c}35 \\
(6.8 \%) \\
\end{array}$ \\
\hline $\begin{array}{l}\text { Sauces \& deserting } \\
\text { (Sauces \& deserting) }\end{array}$ & $\begin{array}{c}7 \\
(1.4 \%) \\
\end{array}$ & $\begin{array}{c}11 \\
(2.2 \%) \\
\end{array}$ & $\begin{array}{c}29 \\
(5.6 \%) \\
\end{array}$ & $\begin{array}{c}26 \\
(5.1 \%) \\
\end{array}$ & $\begin{array}{c}87 \\
(16.9 \%) \\
\end{array}$ & $\begin{array}{c}287 \\
(55.8 \%) \\
\end{array}$ & $\begin{array}{c}67 \\
(13 \%) \\
\end{array}$ \\
\hline $\begin{array}{l}\text { Dairy and Meat Products } \\
\text { (Cheese, Yoghurt, Ice cream, } \\
\text { Flavored milk, Dried milk, } \\
\text { Processed meat and Chicken } \\
\text { products) }\end{array}$ & $\begin{array}{c}42 \\
(8.2 \%) \\
\end{array}$ & $\begin{array}{c}72 \\
(14.0 \%) \\
\end{array}$ & $\begin{array}{c}53 \\
(10.3 \%) \\
\end{array}$ & $\begin{array}{c}85 \\
(16.5 \%) \\
\end{array}$ & $\begin{array}{c}100 \\
(19.5 \%) \\
\end{array}$ & $\begin{array}{c}113 \\
(22.0 \%) \\
\end{array}$ & $\begin{array}{c}49 \\
(9.5 \%) \\
\end{array}$ \\
\hline $\begin{array}{l}\text { Other items }(\mathbf{n}=\mathbf{4}) \\
\text { (Chicken spices, Margarine, } \\
\text { Jam \& Halawa tahini) }\end{array}$ & $\begin{array}{c}21 \\
(4.1 \%)\end{array}$ & $\begin{array}{c}40 \\
(7.7 \%)\end{array}$ & $\begin{array}{c}29 \\
(5.5 \%)\end{array}$ & $\begin{array}{c}36 \\
(7.1 \%) \\
\end{array}$ & $\begin{array}{c}53 \\
(10.3 \%)\end{array}$ & $\begin{array}{c}243 \\
(47.3 \%)\end{array}$ & $\begin{array}{c}92 \\
(18 \%)\end{array}$ \\
\hline Food additives consumption & $\begin{array}{c}24 \\
(4.6 \%) \\
\end{array}$ & $\begin{array}{c}54 \\
(10.5 \%) \\
\end{array}$ & $\begin{array}{c}53 \\
(10.3 \%)\end{array}$ & $\begin{array}{c}64 \\
(12.5 \%) \\
\end{array}$ & $\begin{array}{c}89 \\
(17.3 \%) \\
\end{array}$ & $\begin{array}{c}170 \\
(33.1 \%) \\
\end{array}$ & $\begin{array}{c}60 \\
(11.7 \%) \\
\end{array}$ \\
\hline
\end{tabular}

1000 preschool nursery) Sharkia.gov.eg.

Two preschool nurseries were selected randomly to represent urban and rural areas of each district. So, four preschool nurseries were selected to represent Sharkia governorate. Sample units were collected as clusters from each nursery.

Preschool children and their parents with the following inclusion criteria; mothers aged 18 years old or older and preschool children of both sexes, and exclusion criteria were mothers or children with difficulty in communication and children with food allergies were excluded.

Study description and data collection
Preparation stage: The labels of 60 commonly marketed food products were analyzed for the presence of various food additives, based on a review of the literature at this stage the tools used in the study were constructed to fit the Egyptian patients. Before the start of the study, the tools have been pre-tested to ensure that the wording, format, length, and sequencing of questions are appropriate.

Pilot study: A pilot study was conducted on 30 participants and a validity test for language clarity, content, relevancy, ease of understanding and time needed to answer was done on the questionnaire. A 
reliability test was done by using the reliability coefficients (Cronbach's alpha) which was high for all questionnaires, and suitable for scientific purposes. The results

Table (3): Number of food additives present in some inspected food products.

\begin{tabular}{|c|c|c|c|c|c|c|c|}
\hline \multirow{2}{*}{ Food products } & \multicolumn{7}{|c|}{ No. of Food additives present in inspected food items } \\
\hline & No & One & Two & Three & Four & Five & $>$ Five \\
\hline $\begin{array}{l}\text { Crisps \& crackers }(\mathbf{n}=\mathbf{8}) \\
8 \text { products of (chips, wheat } \\
\text { crackers \& corn crackers) }\end{array}$ & & $\begin{array}{c}2 \\
(25 \%) \\
\end{array}$ & $\begin{array}{c}3 \\
(37.5 \%)\end{array}$ & $\begin{array}{c}2 \\
(25 \%) \\
\end{array}$ & -- & $\begin{array}{c}1 \\
(12.5 \%)\end{array}$ & - \\
\hline $\begin{array}{l}\text { Cereals, Biscuits \& Cakes }(\mathbf{n}=\mathbf{1 5}) \\
15 \text { products of (Bakery, pies, pizza } \\
\text { Noodles \& pasta, Biscuits, Cakes } \\
\text { and Fries) }\end{array}$ & ------ & $\begin{array}{c}1 \\
(6.67 \%)\end{array}$ & $\begin{array}{c}5 \\
(33.3 \%) \\
\end{array}$ & $\begin{array}{c}3 \\
(20 \%) \\
\end{array}$ & $\begin{array}{c}1 \\
(6.7 \%) \\
\end{array}$ & $\begin{array}{c}2 \\
(13.3 \%) \\
\end{array}$ & $\begin{array}{c}3 \\
(20 \%) \\
\end{array}$ \\
\hline $\begin{array}{l}\text { Juices \& Beverages }(\mathbf{n}=\mathbf{8}) \\
8 \text { products of (Juices and Soda } \\
\text { beverages) }\end{array}$ & ---- & ----- & $\begin{array}{c}2 \\
(25 \%) \\
\end{array}$ & $\begin{array}{c}3 \\
(37.5 \%) \\
\end{array}$ & $\begin{array}{c}2 \\
(25 \%) \\
\end{array}$ & $\begin{array}{c}1 \\
(12.5 \%)\end{array}$ & ----- \\
\hline $\begin{array}{l}\text { Candies \& chocolate }(n=4) \\
4 \text { products of (Candies and } \\
\text { Chocolate) }\end{array}$ & $\begin{array}{c}1 \\
(25 \%)\end{array}$ & $\begin{array}{c}1 \\
(25 \%) \\
\end{array}$ & ---- & $\begin{array}{c}1 \\
(25 \%)\end{array}$ & ------ & ------ & $\begin{array}{c}1 \\
(25 \%)\end{array}$ \\
\hline $\begin{array}{l}\text { Sauces \& deserting }(\mathbf{n}=\mathbf{3}) \\
3 \text { products of (Sauces \& deserting) }\end{array}$ & ----- & $\begin{array}{c}1 \\
(33.3 \%)\end{array}$ & ----- & ---- & ----- & $\begin{array}{c}1 \\
(33.3 \%)\end{array}$ & $\begin{array}{c}1 \\
(33.3 \%)\end{array}$ \\
\hline $\begin{array}{l}\text { Dairy and Meat Products }(\mathbf{n}=\mathbf{1 8}) \\
18 \text { products of (Cheese, Yoghurt, } \\
\text { Ice cream, Flavored milk, Dried } \\
\text { milk, Processed meat and Chicken } \\
\text { products) }\end{array}$ & ---- & $\begin{array}{c}3 \\
(16.7 \%) \\
\end{array}$ & $\begin{array}{c}6 \\
(33.3 \%) \\
\end{array}$ & $\begin{array}{c}7 \\
(38.9 \%) \\
\end{array}$ & $\begin{array}{c}1 \\
(5.5 \%) \\
\end{array}$ & ---- & $\begin{array}{c}1 \\
(5.5 \%) \\
\end{array}$ \\
\hline $\begin{array}{l}\text { Other items }(\mathbf{n}=4) \\
4 \text { products of (Margarine, Jam \& } \\
\text { Halawa tahini) }\end{array}$ & & & $\begin{array}{c}2 \\
(50 \%)\end{array}$ & $\begin{array}{c}2 \\
(50 \%)\end{array}$ & & & \\
\hline Total $=60$ product & $\begin{array}{c}1 \\
(1.7 \%) \\
\end{array}$ & $\begin{array}{c}8 \\
(13.3 \%)\end{array}$ & $\begin{array}{c}18 \\
(30 \%) \\
\end{array}$ & $\begin{array}{c}18 \\
(30 \%)\end{array}$ & $\begin{array}{c}4 \\
(6.7 \%) \\
\end{array}$ & $\begin{array}{c}5 \\
(8.33 \%) \\
\end{array}$ & $\begin{array}{c}6 \\
(10 \%) \\
\end{array}$ \\
\hline
\end{tabular}

Study description: A semi - structured questionnaire in the native Arabic language adapted from previous studies was used, consists of 3 parts: Part I: sociodemographic information using (Fahmy et al., 2015) ${ }^{18}$ asking about (age, gender, educational level, employment status, residency, income level, number of family members, their ages, sewage, and refusal system), Part II: a structured food frequency questionnaire containing the most popular consumed food products among preschool children, Part III: Questions about food additives knowledge, and attitude towards food additives adopted from previous study. ${ }^{19}$ The questionnaire was distributed to be

The Egyptian Journal of Community Medicine of the pilot study showed no difference from the main results so it was included in the main results. 
nutrition experts. It contained 32 food items popularly consumed by preschool children, such as; biscuits, fries, cake, lollipops, proceed foods, sweets, and crackers. The frequency was rated on a 7-point Likert

Table (4): Food additives following E-numbering system found in some food products

\begin{tabular}{|c|c|c|c|c|c|c|c|}
\hline $\begin{array}{c}\text { Groups of } \\
\text { food } \\
\text { products }\end{array}$ & Crisps & $\begin{array}{l}\text { Biscuits \& } \\
\text { cakes }\end{array}$ & $\begin{array}{c}\text { Juices \& } \\
\text { beverages }\end{array}$ & $\begin{array}{l}\text { Candies \& } \\
\text { chocolates }\end{array}$ & $\begin{array}{r}\text { Sauces \& } \\
\text { dressing }\end{array}$ & $\begin{array}{c}\text { Dairy } \\
\text { products }\end{array}$ & $\begin{array}{c}\text { Other } \\
\text { consumer } \\
\text { goods }\end{array}$ \\
\hline $\begin{array}{l}\text { E } \\
\text { number } \\
\text { content }\end{array}$ & $\begin{array}{l}\text { E100, } \\
\text { E150a, } \\
\text { E160a, } \\
\text { E160b, } \\
\text { E160c, } \\
\text { E162, } \\
\text { E262, } \\
\text { E270, } \\
\text { E296, } \\
\text { E307, } \\
\text { E327, } \\
\text { E330, } \\
\text { E339, } \\
\text { E341, } \\
\text { E443, } \\
\text { E471, } \\
\text { E508, } \\
\text { E551, } \\
\text { E552, } \\
\text { E621, } \\
\text { E627, } \\
\text { E631, } \\
\text { E635 }\end{array}$ & $\begin{array}{l}\text { E150d, } \\
\text { E200, } \\
\text { E202, } \\
\text { E223, } \\
\text { E320, } \\
\text { E321, } \\
\text { E322, } \\
\text { E330, } \\
\text { E415, } \\
\text { E420, } \\
\text { E421, } \\
\text { E450, } \\
\text { E452, } \\
\text { E466, } \\
\text { E470, } \\
\text { E470a, } \\
\text { E471, } \\
\text { E475, } \\
\text { E476, } \\
\text { E500, } \\
\text { E500ii, } \\
\text { E503, } \\
\text { E520, } \\
\text { E1422, } \\
\text { E1520 }\end{array}$ & $\begin{array}{l}\text { E102, } \\
\text { E150d, } \\
\text { E211, } \\
\text { E296, } \\
\text { E330, } \\
\text { E407, } \\
\text { E414, } \\
\text { E444, } \\
\text { E445, } \\
\text { E471, } \\
\text { E1450 }\end{array}$ & $\begin{array}{l}\text { E100, } \\
\text { E133, } \\
\text { E160a, } \\
\text { E162, } \\
\text { E171, } \\
\text { E172, } \\
\text { E330, } \\
\text { E322, } \\
\text { E500, } \\
\text { E903, } \\
\text { E1400 }\end{array}$ & $\begin{array}{l}\text { E160a, } \\
\text { E202, } \\
\text { E207, } \\
\text { E211, } \\
\text { E306, } \\
\text { E330, } \\
\text { E321, } \\
\text { E412, } \\
\text { E415 }\end{array}$ & $\begin{array}{ll}\text { E111, } & \text { E202, } \\
\text { E234, } & \text { E331, } \\
\text { E322, } & \text { E339, } \\
\text { E401, } & \text { E407, } \\
\text { E410, } & \text { E412, } \\
\text { E415, } & \text { E421, } \\
\text { E441, } & \text { E450, } \\
\text { E452, } & \text { E471, } \\
\text { E575, } & \text { E1400 }\end{array}$ & $\begin{array}{l}\text { E319, E322, } \\
\text { E330, E440, } \\
\text { E471, E621, } \\
\text { E627, E631 }\end{array}$ \\
\hline
\end{tabular}

scale where: 1 for Not used, and 7 for use more than 1 time/day, total score was calculated by adding all scored items together, higher scores indicate more food consumption and greater exposure to food additives, Cronbach's Alpha $=0.92$.

Scoring of Knowledge: The knowledge section contained 12 questions to assess knowledge of mothers about food additives regarding the definition of food additives, the role of food additives, the difference between natural and artificial, the effect on food, the effect of $\mathrm{Na}$ Sulphates, the effect of artificial colors, meaning of E-221, electronic E-numbering and effect of additives following E-numbering.

knowledge was calculated in each question as questions permit only one answer, answers were coded as 1 degree for the right answer and Zero degree for the wrong answer or don't know. Total knowledge was scored; frequency of correct knowledge was calculated manually while total knowledge score was calculated using the SPSS program Scoring of attitudes: Attitude of mothers toward food additives and its effects on health, measured using 5 questions, and was scored either agree or don't agree or neutral regarding the harmfulness of Food packing and food additives, food colors, the importance of reading a food label, the total attitude score was rated by summation of 5 attitude questions.

Anthropometric assessment: weight and height were measured, BMI was calculated for children 
over the age of 2 years only, using BMI Calculator for Child and Teen, based on the CDC growth charts for children and teens (ages 2 through 19

years), available at; https://www.cdc.gov/ healthyweight/bmi/calculator.html. Child is

Table (5): Knowledge and attitude of mothers about food additives and its effects on health $(\mathbf{n}=514)$

\begin{tabular}{|c|c|c|c|c|c|c|}
\hline \multirow{2}{*}{ Knowledge of mothers about food additives } & \multicolumn{2}{|c|}{ Correct answer } & \multicolumn{2}{|c|}{ Incorrect answer } & \multicolumn{2}{|c|}{$\begin{array}{l}\text { Don't } \\
\text { Know }\end{array}$} \\
\hline & No. & $\%$ & No. & $\%$ & No. & $\%$ \\
\hline Def. of food additives & 174 & 33.9 & 234 & 45.5 & 106 & 20.6 \\
\hline Role of food additives & 312 & 60.7 & 152 & 29.6 & 50 & 9.7 \\
\hline Difference between natural and artificial & 244 & 47.5 & 132 & 25.7 & 134 & 26.9 \\
\hline Effect on food & 148 & 28.8 & 178 & 34.6 & 188 & 36.6 \\
\hline Effect of Na Sulphates & 78 & 15.2 & 144 & 28.0 & 292 & 56.8 \\
\hline Effect of artificial colors & 162 & 31.5 & 138 & 26.8 & 214 & 41.6 \\
\hline Meaning of E-221 & 16 & 3.1 & 172 & 33.5 & 326 & 63.4 \\
\hline what is aspartame & 68 & 13.2 & 186 & 36.2 & 260 & 50.6 \\
\hline word not containing food additive & 194 & 37.7 & 274 & 53.3 & 46 & 8.9 \\
\hline word diet in food lable & 116 & 22.6 & 166 & 32.3 & 232 & 45.1 \\
\hline Electronic E-numbering & 70 & 13.6 & 190 & 37.0 & 254 & 49.4 \\
\hline Effect of additives following E-numbering & 146 & 28.4 & 132 & 25.7 & 236 & 45.9 \\
\hline Total Knowledge score & 144 & 28.0 & 174 & 34.0 & 196 & 38.0 \\
\hline Attitude of mothers Toward food additives & \multicolumn{2}{|l|}{ Agree } & \multicolumn{2}{|l|}{ neutral } & \multicolumn{2}{|c|}{ Don't Agree } \\
\hline Food packing is Harmful & 292 & 56.8 & 122 & 23.7 & 100 & 19.5 \\
\hline More food additives are Harmful & 320 & 62.3 & 156 & 30.4 & 38 & 7.4 \\
\hline Foods containing colors not useful & 326 & 63.4 & 100 & 19.5 & 88 & 17.1 \\
\hline Food additives more attractive & 232 & 45.1 & 216 & 42.0 & 66 & 12.8 \\
\hline Reading nutrition facts labels is important & 118 & 23.0 & 0 & 0.0 & 396 & 77.0 \\
\hline Total Attitude score & 129 & 50.1 & 59 & 23.1 & 69 & 26.8 \\
\hline
\end{tabular}

considered wasted if Z- score of weight for age is $<2$, and the child is considered stunted if Z-score of height for age $<2$, The expert committee recommended classifying BMI at the $85^{\text {th }}$ to $95^{\text {th }}$ percentiles for age and sex to identify children who are overweight, a BMI greater than or equal to the $95^{\text {th }}$ percentile to identify children who are obese and the cutoff for underweight of less than the $5^{\text {th }}$ percentile of BMI-for-age.(20)

\section{Statistical analysis:}

The collected data were analyzed by computer using Statistical Package of Social Services version 24 (SPSS), Data were represented in tables and graphs, Continuous quantitative variables e.g. age, weight, height, and BMI were expressed as mean \pm SD \& (range), and categorical qualitative variables were expressed as number and percentage, suitable statistical tests were used, Pearson's correlation coefficient (r) was calculated as a measure of the strength of the association between two numeric variables, Student T-test was used for dependent quantitative variables, the results were considered highly statistically significant when the significant probability was less than $0.001(\mathrm{P}<0.001)$.

\section{Ethical Considerations}

Ethical considerations were taken through the whole study including fully informed participants with the purpose and nature of the study and then oral consent was taken from participants. Official approval from the Institutional review board (IRB) was taken (ZU-IRB \#6239).

\section{Results}

The current study included 514 preschool children, the mean age of the studied children was $3.4 \pm 1.18$ years old, with a range from 1 to 5 years old, more than half of them were male (57.6\%), and (42.4\%) were females, Father of about $50 \%$ of the studied
The Egyptian Journal of Community Medicine
Vol. 39
No. 3
July
2021 
children were university-educated (53.6\%) versus $36.9 \%$ of mothers were Table (6): Correlation matrix between food additives consumption, BMI among the studied children, Knowledge and Attitude of mothers toward food additives among the studied group.

\begin{tabular}{|c|c|c|c|c|c|c|}
\hline \multicolumn{2}{|c|}{ Pearson Correlation } & $\begin{array}{l}\text { Socioeconomic } \\
\text { status (SES) }\end{array}$ & Weight & $\begin{array}{c}\text { Total } \\
\text { knowledge }\end{array}$ & $\begin{array}{c}\text { Total } \\
\text { attitude }\end{array}$ & $\begin{array}{c}\text { Food additives } \\
\text { consumption }\end{array}$ \\
\hline \multirow{2}{*}{ Weight } & $\mathrm{r}$ & $.149^{*}$ & & & & \\
\hline & $\mathrm{p}$ & .019 & & & & \\
\hline \multirow{2}{*}{$\begin{array}{l}\text { Total } \\
\text { knowledge }\end{array}$} & $\mathrm{r}$ & $.374^{3 *}$ & -.012 & & & \\
\hline & $\mathrm{p}$ & .000 & .847 & & & \\
\hline \multirow{2}{*}{$\begin{array}{l}\text { Total } \\
\text { attitude }\end{array}$} & $\mathrm{r}$ & $.196^{* *}$ & .006 & $.364^{* *}$ & & \\
\hline & $\mathrm{p}$ & .002 & .923 & .000 & & \\
\hline \multirow{2}{*}{$\begin{array}{l}\text { Food additives } \\
\text { consumption }\end{array}$} & $\mathrm{r}$ & $-.233^{* *}$ & .031 & $-.194^{* *}$ & .089 & \\
\hline & $\mathrm{p}$ & .000 & .631 & .002 & .157 & \\
\hline \multirow{2}{*}{ BMI in > 2 years } & $\mathrm{r}$ & .150 & $.660^{* * 4}$ & .116 & .034 & $.182 *$ \\
\hline & $\mathrm{p}$ & .072 & .000 & . 166 & .690 & .030 \\
\hline
\end{tabular}

*. Correlation is significant at the 0.05 level (2-tailed). **. Correlation is significant at the 0.01 level (2-tailed). university educated, despite that half of the food products contains two or three mothers were working $(54.9 \%)$, most of the studied groups had moderate socioeconomic status and high socioeconomic status $(20.2 \%$ and $79.4 \%$, respectively) and only $0.4 \%$ of them of low socioeconomic status. Regarding anthropometric assessment, most of the studied children $(94.5 \%$ \& $95.1 \%)$ were normal height-and weight-for-age (Table 1).

Food additives consumption was on a daily base among $15.1 \%$ of the studied preschool children, The food items that were highly consumed more than once/day include biscuits, fries, cake, processed cheese, and lollipops in $(19.5 \%, 10.9 \%$, $10.1 \%, 11.3 \%$, and $8.2 \%$ respectively), Foods mostly consumed once per day were fries (27.6\%), Biscuits (24.5\%), lollipops $(24.1 \%)$, cake \& chocolate $(20.6 \%$ and $22.2 \%$, respectively), and flavored milk (19.5\%), Foods mostly consumed 4-5 times weekly were Bakery (19.1\%), Biscuits (21\%), cakes $(26.1 \%)$, chocolates (28.4\%), Chips, Corn crackers, and Wheat crackers in $(15.2 \%, 14.8 \%$ \& $19.8 \%$, respectively)(Table 2 ).

This survey revealed that $10 \%$ of the products contained five or more additives (three of them belong to the cereals, biscuits \& cakes). A higher percentage of additives (30\% each) with the majority belong to dairy, meat products, and crisps. In all selected food categories, the common food additives were citric acid (E330) except in dairy and meat products was shown in (Table 3).

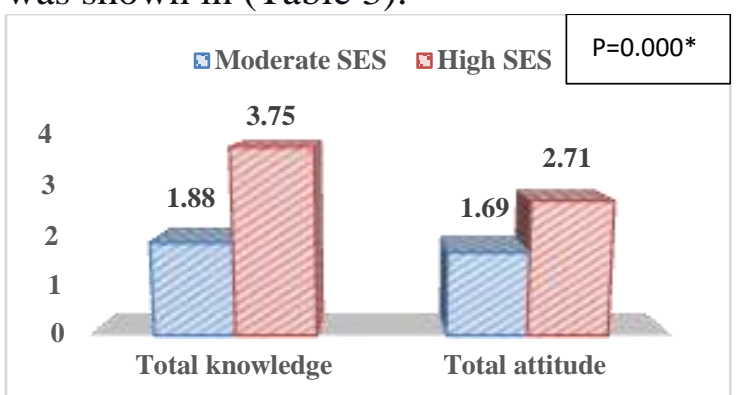

Figure (1): Knowledge and Attitude of mothers toward food additives in relation to their socioeconomic status. (Data expressed in mean, * p-value is significant)

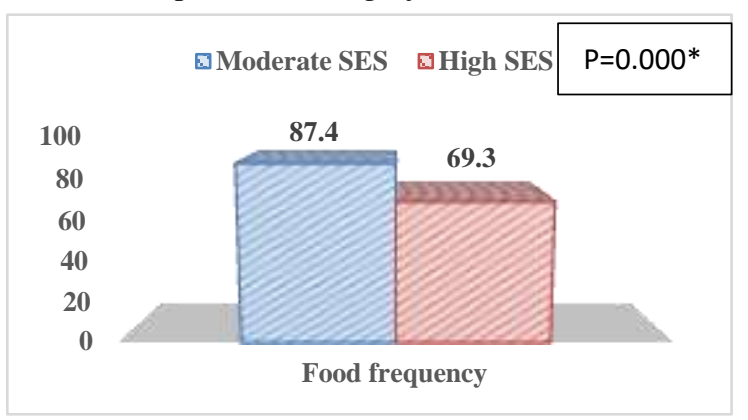

Figure (2): Food additives consumption in relation to socioeconomic status among the studied mothers.

Regarding the distribution of various food additives, Crisps and Biscuits \& cakes foods 
contain 23-27 food additives from various groups, E100-E199 (colors), E200-E299 (preservatives), E300-E399 (antioxidants, acidity regulators), E400-E499 (thickeners, stabilizers, emulsifiers), E600-E699 (flavor enhancer), E330 or Citric Acid was found in Crisps, Biscuits \& cakes, Juices \& beverages, candies, and Sauces, \& dressing (Table 4).

Twenty-eight (28) \% of the studied mothers had satisfactory knowledge about food additives, while $34 \%$ of them giving an incorrect answer and 38\% don't know about food additives, $50.1 \%$ of the studied mothers agree that Food packing is Harmful, more food additives are Harmful, Foods containing colors not useful, Food additives added for more attraction, reading nutrition facts labels is important (Table 5).

There was a significant positive correlation between socioeconomic status, total knowledge, and attitude toward food additives $(r=0.374,0.196$, $p$-value $<0.05)$ respectively, but there was a significant negative correlation between Socioeconomic status and food additives consumption where the higher socioeconomic status the lower consumption of food additives. There was a positive significant correlation between total knowledge of mothers and attitude, but there was a negative significant correlation between total knowledge of mothers and food additive consumption ( $\mathrm{r}=$ -0.194, p<0.01), mothers use food containing additive less when they know more about it. There was a significant positive correlation between food containing food additives consumption and BMI. (Table 6).

There was a significant difference between moderate and high Socioeconomic status as regard knowledge, attitude about food additives, and food additives consumption where knowledge and attitude significantly higher among high socioeconomic status while food additives consumption was significantly lower among high socioeconomic status children (Figure 1 \& 2)

\section{Discussion}

Food additives are elements which are not regarded or used as foods themselves but used in or on food to affect its preservation, taste, appearance, consistency, quality, or to help in processing. ${ }^{1}$ Customers express high levels of concern about the use of food additives, worrying about unknown acute and/or chronic health problems. Customers tend to have a negative attitude about "color additives" being linked to behavioral changes in children in some reports. ${ }^{21}$

This study was conducted on 514 children with a mean age of 3.4 years (range 1-5) and their parents. A validated Arabic version of the questionnaire was used to assess the demographic and social status of the parents, $79.4 \%$ of our sample were of high socioeconomic status.

Anthropometric indices, HAZ, WHZ, and WAZ reflect a child's growth over time. Our results showed that most of the studied children $(94.5 \%$ \& $95.1 \%)$ have normal height-and weight-for-age, table 1. Also, we found that $5.5 \%$ of the studied children were stunted, contrarily to our finding, one study in Egypt reported that the prevalence of stunting was $11 \%$ in Upper Egypt and $12 \%$ in Lower Egypt among children less than two years. ${ }^{22}$ This discrepancy may be explained by the higher educational and socioeconomic levels of the surveyed families and the extended age of the children in our study.

Body mass index (BMI) calculation showed that $3.7 \%$ of the children were overweight/obese children. Interestingly, BMI has a significant positive correlation with food additive consumption $(r=0.182$, $\mathrm{p}<0.05$ ), table 6. Indeed, the relationship between obesity and food additives has 
gained attention over the last few years. The effect of additives on cells of the immune system may potentially contribute to the state of chronic low-grade inflammation seen in obesity that contributes to the establishment of insulin resistance and other metabolic abnormalities. This is of relevance given that metabolic dysregulation and obesity have a strong immune-mediated component. ${ }^{23}$ Although citrate is classified as a natural additive, it may contribute to impaired glucose tolerance, low-grade inflammation, and obesity. In mice which receive citrate plus sucrose showed higher fasting blood glucose in a clinical trial. This was accompanied by increased inflammatory cytokines in adipose tissue. ${ }^{24}$ In this regard, data suggest that higher doses of citrate may be pro-inflammatory.

We selected 32 food items based on popularity, availability in supermarkets and small shops, and affordable price covering the five main food groups, Food items that were highly consumed more than once per day include biscuits (19.5\%), processed cheese $(11.3 \%)$, fries $(10.9 \%)$, and cakes $(10.1 \%)$. Again, fries had the highest consumption frequency $(27.6 \%)$ on once-daily bases followed by biscuits (24.5 $\%)$, lollipops (24.1\%), flavored milk (19.5 $\%)$, and processed cheese (18.3\%). Chocolate and cakes showed their highest consumption as 4-5 times per week. Corn crackers, chips, wheat crackers, and bakery showed the highest once per week consumption $(25.7 \%, 24.9 \%, 22.6 \%$, and $20.2 \%$, respectively). Some food items like ketchup/mayonnaise, eastern sweets, processed chicken, diet soda, pickles, margarine, chicken spices, and pizza showed once or less consumption per month. table 2 .

The number of food additives (table 3 ) in each category of food is highly variable. Only one product from the screened 60 products contains no additive, and 10\% (n $=6$ ) contain five or more additives (three of them belong to the cereals, biscuits \& cakes). Higher percentages of food products contain two or three additives (30\% each) with the majority belong to dairy, meat products, and crisps. Certain food additives are commonly used in biscuits, crisps, or dairy products than others. This may be because these additives are a basic element in the production of these products. For instance, flavoring and emulsifiers are essential in biscuits and cakes; taste enhancers and flavoring are important in the production of crisps; preservatives are required in dairy and meat products manufacture. In partial agreement with our results, $\mathrm{Al}$ Harthy et al., ${ }^{6}$ demonstrated that food additives were more abundant in crisps compared to biscuits and juices in selected products in Muscat, Oman.

Special attention should be taken to some products that may be used as a complementary feeding in young children, e.g., yogurt and dried/flavored milk. The examined yogurt products contained one natural additive (gelatin, E471). The dried milk contained soya lecithin (E322) and the flavored milk contained emulsifier (E471), artificial flavoring, and food stabilizer (E407). Within the juices and beverages, all products contain two or more additives. One study in Brazil examined children's products reported that 19 milk powder products contain one additive, two products contain two additives and one product contains three additives. Our study showed that within the cereals, $33.3 \%(n=5)$ of the products contain two additives and $20 \% \quad(n=3)$ contains three additives. The additives noted in this category were sodium bicarbonate (E500), soybean lecithin (E322), and citric acid (E330). Similarly, 
the same additives were reported within the cereal children products in Brazil. ${ }^{4}$

Analysis of our results showed that certain categories of food items contain more food additives than the others, table 4 . A large number of food additives are present in biscuits and cakes $(n=25)$, crisps $(n=23)$, and dairy and meat products $(\mathrm{n}=18)$ compared with other food categories. This could be explained by that biscuits, cakes, and crisps are marketed in different kinds, forms, and flavors. In all selected food categories, the common food additives were citric acid (E330) except in dairy and meat products. Also, mono- and diglycerides of fatty acids (E471) emulsifier food additive was the second common except in candies, sauces, and deserts. In agreement with our results, Al-Harthy et $a l .{ }^{6}$ reported that citric acid (E330) was the common additives in crisps, biscuits, and fruit juices in the Omani market.

Moreover, the current study revealed that coloring additives are common in candies, chocolates, and crisps. We reported Brilliant Blue (E133), Beta Carotene (E160a), Beet road Red (E162), and Titanium Dioxide (E171). In India, a study investigated the types and levels of color additives added to various foods in the city of Hyderabad and surrounding rural areas. Among the 700 food items collected from urban areas and 300 from rural areas, 93\% and $95 \%$ of the products (respectively) were found to contain permitted color additives. $^{25}$

In this study, only $28 \%$ of the studied mother had satisfactory knowledge about food additives; while $34 \%$ of them giving an incorrect answer and $38 \%$ of the mothers responded by don't know. Hopefully, the greater proportions of the surveyed mothers had correct information about the role of food additive $(60.7 \%)$ and can differentiate between natural and artificial additives (47.5\%). In parallel to our results, one survey reported that more than $50 \%$ of consumers surveyed correctly responded to the same questions. ${ }^{19}$ However, another research report in Korea ${ }^{26}$ showed that most of the consumers tend to have low knowledge and understanding of food additives which may be due to different data collection technique, namely the semi-structured interview rather than standard questionnaires.

Table 5 showed that a very low percentage $(3.1 \%)$ of surveyed mothers correctly answered the meaning of E-numbers. Similarly, a food additive survey in Muscat, Oman showed that participants didn't have enough knowledge regarding the E-numbers or their impact on health status. ${ }^{6}$ This finding denotes a lack of awareness of the E-numbering system of food additives and subsequently lack of risk/benefit assessment which is in agreement with the previous literature report. $^{26}$ E-numbers conveys that food additives used had obtained safety clearance and are approved for use by the FDA and European Union. The main purpose of developing the E-numbers was to make food labels easier to grab. ${ }^{27}$ Our finding requires urgent consumer educational plans to help them understand the E-numbers, proper safe food item selection, and avoidance of possible hazardous additives. Regarding the attitude towards the food additives, the major percent of the studied mothers agreed to the following: food packing is harmful $(56.8 \%)$, more food additives are harmful $(62.3 \%)$, foods containing colors are not useful $(63.4 \%)$, and food additives are added for more attraction (45.1\%). Unfortunately, $77 \%$ disagreed that reading nutrition facts labels is important, in table 5. One report found a positive correlation between knowledge and food label use. So, nutrition awareness helps to direct 
attention to salient data, promoting understanding, and used in proper healthful decision making. ${ }^{28}$ Similar to our results, Koyratty, et al. ${ }^{19}$ showed that $65 \%$ of the responded Mauritian population never checked food labels for additives and the respondents had an overall poor knowledge of food additives.

Our results revealed a significant difference between moderate and high Socioeconomic status as regard total knowledge score of food additives (mean \pm SD: $1.88 \pm 1.73$ vs. $3.75 \pm 2.30, p<0.001$ ) and food additives consumption (mean \pm SD: $87.42 \pm 20.19$ vs. $69.36 \pm 28.27, p<$ $0.001)$. Interestingly, the total knowledge score was significantly higher among high socioeconomic status; while Food additives consumption was significantly lower among high socioeconomic status, Figure (1\&2). Besides, our results showed that there is a statistically significant positive correlation between socioeconomic status and total knowledge score $(\mathrm{r}=0.374, p<0.001)$, table 6. This result appears to agree with Koyratty et al. (19) who reported a statistically significant relationship was obtained between knowledge of food additives and the education level of respondents. Indeed, knowledge of food additives increases with an increasing level of education.

A recent study indicated that the higher the level of paternal education, the lower the consumption of foods containing FDAprohibited artificial color. Students whose fathers had lower educational levels were more likely to consume more prohibited food items than their counterparts. ${ }^{29}$

\section{Conclusion}

A relatively large percent of preschool children consumes plenty of foods containing food additives on a daily base, the majority of the marketed foods products contains 2-5 different food additives, there is unsatisfied public awareness regarding food additives and the E-numbering system and the importance of reading food labels although its high consumption and its avoidable risk. Level of education and knowledge about food additives have a great effect on attitude towards it and the frequency of its consumption

Recommendations: Nutritional health education concerning food additives is essentially required for families and communities that will help in guidance of children for healthy food choices properly and will positively impact family health for the upcoming generations.

Study limitations: This study has some limitations; first, it was performed only at one governorate (Al sharkia) in Egypt. Second, this study did not measure the harmful effects of food additives among preschool children. Third, the study didn't include quantitative analysis of the amount of additives in the selected food items and if their use is within the accepted daily intake.

Authors' contribution: M.S.H. contributed to the planning of the work, drafting of the work, data collection, statistical analysis, reporting, literature review, revision of the manuscript, approval of the final version of the manuscript, and agreed to all aspects of the work.

N.O.F and H.N.A. contributed to data collection, revision of the manuscript, approval of the final version of the manuscript, and agreed to all aspects of the work.

Conflict of interest: No known conflicts of interest associated with this publication.

Funding: there has been no financial support for this work.

Acknowledgment: we would like to express great thanking to the participants for their help to accomplish this work.

References:

The Egyptian Journal of Community Medicine

Vol. 39

No. 3

July

2021 
1. Saltmarsh, M., \& Saltmarsh, M. (Eds.). (2013). Essential guide to food additives. Royal Society of Chemistry.

2. Neltner TG, Kulkarni NR, Alger HM, et al. (2011): Navigating the U.S. Food Additive Regulatory Program. Compr Rev Food Sci Food Saf. 10(6):342-368.

3. Ilbäck, N. G., \& Busk, L. (2000): Food additatives. Use, intake and safety. Näringsforskning, 44(1), 141-149.

4. Lorenzoni, A. S. G., Oliveira, F. A., \& Cladera-Oliveira, F. (2012): Food additives in products for children marketed in Brazil. Food and Public Health, 2(5), 131-136.

5. Trasande L, Shaffer RM, Sathyanarayana $S$ (2018): Food additives and child health. Pediatrics. 142(2):e20181410.

6. Al-Harthy, A. M., Harib, A., Al-Shaaibi, A. J., Al-Toubi, S. S., \& AbuKhader, M. M. (2017): Food Additives Content in Selected Snack Foods and Beverages and Public Perception of E-Numbers in Muscat, Oman. ATHENS Journal of Health, 4(1), 83.

7. Worm M, Vieth W, Ehleres I, Sterry W, \& Zuberbier $T$ (2001): Increased leukotriene production by food additives in patients with atopic dermatitis and proven food intolerance. Clinical and Experimental Allergy, 31(2), 265273.

8. Shimada C, Kano K, Sasaki YF, Sato I, \& Tsudua S (2010): Differential colon DNA damage induced by azo food additives between rats and mice. The journal of toxicological sciences, 35(4), 547-554.

9. Knekt P, Jarvinen R, Dich J, \& Hakulinen T (1999): Risk of colorectal and other gastrointestinal cancers after exposure to nitrate, nitrite and N-nitroso compounds: A follow-up study. International Journal of Cancer, 80(6), 852-856.

10.Bateman B, Warner JO, Hutchinson E, Dean T, Rowlandson P, Gant C, Grundy J, Fitzgerald C, \& Stevenson J (2004): The effects of a double blind, placebo controlled, artificial food colourings and benzoate preservative challenge on hyperactivity in a general population sample of preschool children. Archives of Disease in Childhood, 89(6), 506-511.
11.McCann D, Barrett A, Cooper A, Crumpler D, Dalen L, Grimshaw K, Kitchin E, Lok K, Porteous L, Prince E, et al. (2007): Food additives and hyperactive behaviour in 3-yearold and 8/9-year-old children in the community: a randomised, double-blinded, placebo-controlled trial. Lancet, 370, 1560-67. 12.Landrigan PJ \& Goldman LR (2011): Children's vulnerability to toxic chemicals: a challenge and opportunity to strengthen health and environmental policy. Health Aff (Millwood);30(5):842-850.

13.Polônio MLT \& Peres F (2009): Food additive intake and health effects: public health challenges in Brazil. Cadernos de Saúde Pública, 25(8), 1653-1666.

14. Huybrechts I, Sioen I, Boon PE et al. (2011): Dietary exposure assessments for children in Europe (the EXPOCHI project): rationale, methods and design. Arch Public Health 69,1-12.

15.WHO Multi center Growth Reference Study Group (2006): WHO Child Growth Standards based on length/height, weight and age. Acta paediatrica Supplement, 450, 76-85.

16. Wilson NK, Chuang JC, Morgan MK et al. (2007): An observational study of the potential exposures of preschool children to pentachlorophenol, bisphenol-A, and nonylphenol at home and daycare. Environ Res 103, 9-20.

17.CAPMAS.gov.eg. (2017): Central Authority for Public Mobilization and Statistics. Available from: http://www.capmas.gov.eg /Pages/StaticPages.aspx?page_id =7188.

(Accessed: October 5, 2019).

18.Fahmy, S. I., Nofal, L. M., Shehata, S. F., El Kady, H. M., \& Ibrahim, H. K. (2015): Updating indicators for scaling the socioeconomic level of families for health research. Journal of the Egyptian Public Health Association, 90(1), 1-7.

19.Koyratty, B. N. S., Aumjaud, B., \& Neeliah, S. A. (2014): Food additive control: a survey among selected consumers and manufacturers. British Food Journal.

20.Center for disease prevention and control (CDC) (2014): Growth Chart Training, Division of Nutrition, Physical Activity, and 
Obesity, available at: https://www.cdc.gov/nccdphp/dnpao/growthch arts/training/bmiage/page4.html. (accessed 15 November 2020).

21. Nigg JT, Lewis K, Edinger T, Falk M. (2012): Meta-analysis of attentiondeficit/hyperactivity disorder or attentiondeficit/hyperactivity disorder symptoms, restriction diet and synthetic food color additives. J Am Acad Child Adolesc Psychiatry.;51:86-97.

22.Kavle, J., Mehanna, S., Saleh, G., Foaud, M., Ramzy, M., Hamed, D., ... \& Galloway, R. (2014): Examining factors associated with stunting in Lower Egypt in comparison to Upper Egypt. Bridging the gap between cultural beliefs and feasible feeding practices through Trials for Improved Practices, Washington DC.

23.Paula Neto, H. A., Ausina, P., Gomez, L. S., Leandro, J. G., Zancan, P., \& Sola-Penna, M. (2017): Effects of food additives on immune cells as contributors to body weight gain and immune-mediated metabolic dysregulation. Frontiers in immunology, 8, 1478.

24.Leandro JGB, Espindola-Netto JM, Vianna MCF, Gomez LS, DeMaria TM, MarinhoCarvalho MM, et al. (2016): Exogenous citrate impairs glucose tolerance and promotes visceral adipose tissue inflammation in mice.
$\mathrm{Br} \quad \mathrm{J} \quad$ Nutr 115:967-73. doi:10.1017/S0007114516000027.

25.Rao P., \& Bhat, R.V. (2003): A comparative study on the synthetic food colours usage in foods procured from urban and rural areas of Hyderabad. Nutrition \& Food Science, 33(5), 230 -234,.

26.Shim, S., Seo, S.H., Lee, Y., Moon, G.I., Kim, M. and Park, J. (2011): "Consumers' knowledge and safety perception of food additives: evaluation on the effectiveness of transmitting information on preservatives", Food Control, Vol. 22 No. 7, pp. 1054-1060.

27.Food Standards Agency (FSA) (2009): Public Attitudes to Food, available at: www.food.gov.uk/multimedia/pdfs/publicattit udestofood.pdf (accessed 10 September 2010).

28.Miller, L. M. S., \& Cassady, D. L. (2015): The effects of nutrition knowledge on food label use. A review of the literature. Appetite, 92, 207-216.

29.Oo, N., Saw, Y. M., Aye, H. N. N., Aung, Z. Z., Kyaw, H. N., Tun, A. M., ... \& Hamajima, N. (2019): Consumption of foods containing prohibited artificial colors among middle-school children in Nay Pyi Taw union territory, Myanmar. BMC public health, 19(1), 344. 